\title{
THE EVALUATION OF A RISK DEGREE FOR THE PROCESS OF A BROWN COAL SPONTANEOUS IGNITION ON DUMPS WITH USING OF MODERN NUMERIC METHODS
}

\author{
Petr KLOUDA, Vlastimil MONI, Michal ŘEHǑ̌ \\ Brown Coal Research Institute j. s. C., Most \\ Jan BLATA, František HELEBRANT \\ VŠB-TU Ostrava
}

\begin{abstract}
:
The article is a summary of information about evaluation of a risk degree for a brown coal spontaneous ignition which is realized on the base of a database analysis of information about the development of stative quantities and desorbated gases in the stored bodies of the brown coal. The data were gained from the long term complex measurements which were realized at chosen companies during the coal mining in the previous parts of the project. In the last part of the project, we examined results of temperature models from thermographs with results of gasses and coal samples from the mines. Then, the influence of atmospheric conditions (insolation, water downfall, changes of barometric pressure etc.), the influence of coal mass degradation, the influence of physical and chemical factors, and the influence of other defective factors on the process of the coal spontaneous ignition. The gasmetry was assess with gas in-situ samples and laboratory gas models of indicative gasses for the spontaneous ignition, which were taken from the method of the thermic oxidation with the aim of the correlation finding for an epicentre of temperature within the spontaneous ignition.
\end{abstract}

Key words: spontaneous ignition, brown coal, dumps, evaluation of predisposition to a spontaneous ignition

\section{DATA EVALUATION BASED ON MODERN NUMERIC METHODS APPLICATION}

The correction of a measuring model, the determination of climatic conditions influence, the determination of physical and chemical parameters degradation influence and another failure factor influences to spontaneous ignition processes were realised on the grounds of a long term operating coal dumps measurement analysis. The principles of the estimate of the temperature of a spontaneous ignition epicentre were realised on the grounds of desorbated gases operation sampling with application of verified spontaneous ignition indicative gases figures. The time description of the steam epicentre temperature field development is the result. The calculations are realised by analytical or numerical methods according to a optimal need with application of accessible programmes for partial differential equations, especially statistical methods.

The creation of the simplified steam epicentre model was realised with application of the combination of a temperature field statistical - mathematical description and physical - chemical analysis. The evaluation of a convective oxygen diffusion to the epicentre influence, atmospheric influence etc. is the target of this model.

The preparation of the steam reaction origin and development data is the main target of this research. These steam reaction can be described as the dynamic thermal source. The experimental physical - chemical parameters and new findings about the coal spontaneous ignition critical temperature are these data.

The new mathematical physical model of the dump temperature field was realised. The main factors are $[3,6$, 8]:

- mathematical - physical diagnostics for optimal temperature mapping of the dump (dumps, caving),

- evaluation of non-stationary partial differential equation of heat leading for the stock body with a Newton tangential condition on the surface of the dump and with heat sources presenting the development of the steam reaction,

- processing and interpretation of experimentally discovered physical and chemical quantities in theoretical calculations and models,

- proposals of some experiments and measurements "in situ“ according to the requirements of the theory,

- experimental findings in the fields of dynamics of the coal spontaneous ignition (incubation) and the critical temperature of the coal spontaneous ignition.

COAL SPONTANEOUS IGNITION MODEL IN THE DUMP (3D CFD MODEL) [1, 2, 3, 5, 7, 8]

The model has two domains:

- Heap - coal

- Wind - airflow of the heap by the wind 


\section{COAL DOMAIN}

Coil heap evinces shape of cone:

$\begin{array}{ll}\text { diameter } & 14.00 \mathrm{~m} \\ \text { height } & 5.87 \mathrm{~m} \\ \text { inclination of wall } & 40^{\circ}\end{array}$

Parameters of coal:

$\begin{array}{lll}\text { Moisture } & \text { wt [\%] } & 1.7 \\ \text { Ash } & \text { wt [\%] } & 3.0 \\ \text { Volantility } & \text { wt [\%] } & 33.5 \\ \text { Solid carbon } & \text { wt [\%] } & 63.5 \\ \text { Permeability } & \mathrm{k}\left[\mathrm{m}^{2}\right] & 8.23 \cdot 10-10 \\ \text { Porosity } & \varepsilon[\%] & 10 \\ \text { Grain } & \mathrm{d}[\mathrm{mm}] & 10 \div 20 \\ \text { Predisposition for self-ignition } & \text { category I - high reac- } \\ & & \text { tivity }\left(\mathrm{q}^{30}>7.5 \mathrm{J.g}^{-1}\right)\end{array}$

Heat source:

Arrhenius equation:

$r_{\mathrm{ox}}=\mathrm{A} \cdot \mathrm{CO}^{-e^{-E / R T}}$

$r_{\text {ox }} \quad$ oxidation speed $\quad 1.144\left[\mathrm{~s}^{-1}\right]$

A pre exponential factor $13500\left[\mathrm{~s}^{-1}\right]$

$\mathrm{CO}_{2}$ oxygen concentration -[1] mol share in gas mixture

E activation energy $\quad 50.5\left[\mathrm{~kJ} \cdot \mathrm{mol}^{-1}\right]$

$\mathrm{R} \quad$ gas constant $8.3145\left[\mathrm{~J} .(\mathrm{mol} . \mathrm{K})^{-1}\right]^{\mathrm{N}}$

T temperature $373[\mathrm{~K}]$

Chemical reaction:

Temperature $\mathrm{T}<\mathrm{T}_{\text {th }}$ coal $+\mathrm{O}_{2} \rightarrow 0.1 \mathrm{CO}_{2}+0.4 \mathrm{H}_{2} \mathrm{O}+1.4$ (oxycoal)

Temperature $\mathrm{T}>\mathrm{T}_{\text {th }}$ coal $+\mathrm{O}_{2} \rightarrow 0.2 \mathrm{CO}_{2}+0.01 \mathrm{CO}+0.8 \mathrm{H}_{2} \mathrm{O}$ +0.7 (oxy-coal)

$\mathrm{T}_{\text {th }}$ is critical temperature (the start of oxygen process acceleration and start of temperature increasing).

Components of model:

- Dense net with component height $<0,1 \mathrm{~m}$ to the depth $3 \mathrm{~m}$.

- Maximum height of component inside the heap (maximum $3 \mathrm{~m}$ ).

\section{WIND DOMAIN}

Main parameters:

Wind direction

Wind velocity

Wind temperature

Time course - meteorological station record (is available).

Wind in height $\mathrm{z}: \mathrm{v}_{\mathrm{z}}=\mathrm{v}_{10} \cdot(\mathrm{z} / 10)^{0,22} \mathrm{v}_{10}=4 \mathrm{~m} \cdot \mathrm{s}^{-1}$

Model:

Coal heap situated in homogenous atmosphere.

Airflow of heap - turbulent.

Inside of heap - laminar diffusion with effect of buoyancy.

Model boundary - ca 10x dimension of heap.

\section{DYNAMICAL RELATIONSHIP}

Continuation equation - R1

$$
\frac{\delta}{\delta t} \rho \cdot \gamma+\frac{\delta}{\delta x_{j}}\left(\rho \cdot u_{j}\right)=0
$$

$\rho \quad \square \square \square \square \square$

u $\square \square \square \square \square \square \square \square$

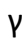

density of mixture $\left[\mathrm{kg} \cdot \mathrm{m}^{-3}\right] ; \rho=1300$ wind velocity vector component $\left[\mathrm{m} \cdot \mathrm{s}^{-1}\right]$ porosity $\left[\mathrm{kg} \cdot{ }^{\mathrm{m}-3}\right] ; 0.15$
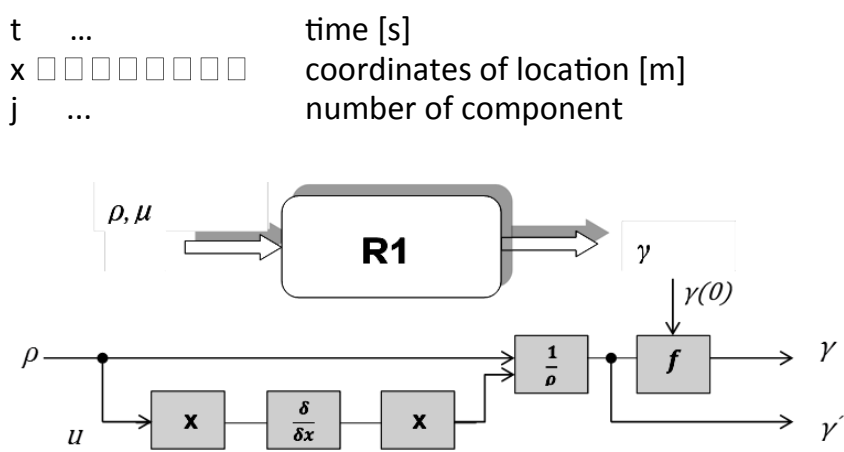

$\frac{\delta\left(\rho \cdot y \cdot \mu_{i}\right)}{\delta t}+\frac{\delta\left(\rho \cdot u_{j} \cdot u_{i}\right)}{\delta x_{j}}=-\frac{\delta p}{\delta x_{i}}+\frac{\delta}{\delta x_{j}}\left(\mu \cdot \frac{\delta u_{i}}{\delta x_{j}}\right)+\rho \cdot f_{i}-\frac{\mu}{\alpha} u_{i}$

Moment equation - R2

$\square \square \square \square \square \square \square \ldots \quad$ density of mixture $\left[\mathrm{kg} \cdot \mathrm{m}^{-3}\right] ; \rho=1300$

$\mathrm{u} \square \square \square \square \square \square \square \ldots \quad$ wind velocity vector component $\left[\mathrm{m} \cdot \mathrm{s}^{-1}\right]$

$\square \square \square \square \square \square \square \ldots \quad$ porosity $\left[\mathrm{kg} \cdot \mathrm{m}^{-3}\right] ; 0.15$

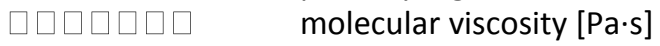

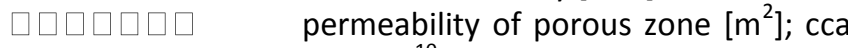
$8.23 \cdot 10^{-10}$

direct relationship between oxidation velocity and coal grain area;

$\mathrm{p} \square \square \square \square \square \square \square \square \ldots$ static pressure [Pa]; from flow calcula tion

$\mathrm{f} \ldots \quad$ gravitation force; gravitation accelera tion

t ..... time [s]

$\mathrm{x} \square \square \square \square \square \square \square \square \ldots$ coordinates of location [m]

$\mathrm{i}, \mathrm{j} \ldots . . . \quad$ number of component

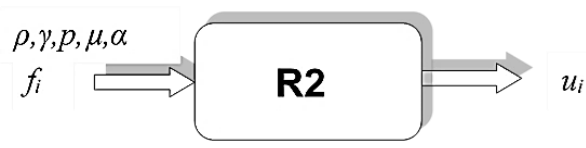

Transport equation - $R 3$

$$
\frac{\delta\left(\rho \cdot y \cdot Y_{i}\right)}{\delta t}+\frac{\delta\left(\rho \cdot u_{j} \cdot Y_{i}\right)}{\delta x_{j}}=-\frac{\delta}{\delta x_{i}} J_{j, i}+R_{i}+S_{i}
$$

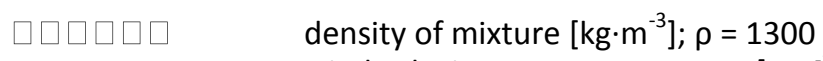

u ... $\square \square \square \square \square \square \square \square$ wind velocity vector component $\left[\mathrm{m} \cdot \mathrm{s}^{-1}\right]$

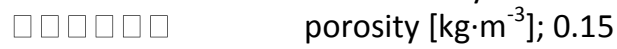

$\mathrm{t}$... time [s]

$\mathrm{x} \square \square \square \square \square \square \square \square \quad$ coordinates of location [m]

$\mathrm{i}, \mathrm{j} \ldots \quad$ number of component

$Y_{i} \ldots \quad$ weight part of component $i$ in mixture [-]

$\mathrm{J}_{\mathrm{j}, \mathrm{i}} \ldots \quad$ diffusion flow between components $\mathrm{j}$

and $\mathrm{i}\left[\mathrm{kg} \cdot \mathrm{m}^{-2} \cdot \mathrm{s}^{-1}\right]$

$\mathrm{R}_{\mathrm{i}} \ldots \quad$ measure of component $\mathrm{i}$ production

$\mathrm{S}_{\mathrm{i}} \ldots \quad$ measure of component $\mathrm{i}$ production by adding from disperse phase $\left[\mathrm{kg} \cdot \mathrm{m}^{-3} \cdot \mathrm{s}^{-1}\right]$

Components: $\mathrm{CO}_{2}, \mathrm{CO}, \mathrm{O}_{2}, \mathrm{CH}_{4}$

$$
\mathrm{J}_{\mathrm{j}, \mathrm{i}} \quad \text { diffusion flow between components } \mathrm{j}
$$
and $\mathrm{i}$

$$
J_{j, i}=\rho \cdot D_{i, m} \frac{\delta Y_{i}}{\delta x_{j}}
$$

$\mathrm{D}_{\mathrm{i}, \mathrm{m}} \square \square \square \square \square \square \square \square$ diffusion coefficient $\left[\mathrm{m}^{-2} \cdot \mathrm{s}^{-1}\right]$; determined on the ground of experience 


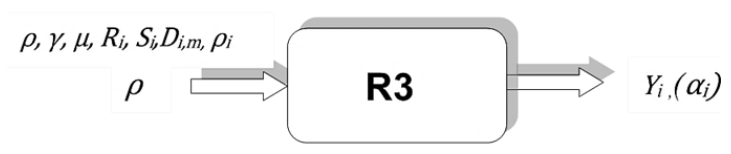

Energy equation - R4

$$
\begin{gathered}
\frac{\delta T}{\delta t}\left(\rho_{g} \cdot y \cdot c_{p g}+(1-\gamma) \rho_{s} \cdot c_{p s}\right)+\frac{\delta}{\delta x_{j}}\left(\rho \cdot u_{j} \cdot c_{p g} \cdot T\right)= \\
=\frac{\delta}{\delta x_{j}}\left(\lambda \cdot \frac{\delta T}{\delta x_{j}}\right)+\frac{\delta}{\delta x_{j}}\left(J_{j, i} \cdot c_{p} \cdot T\right)+S_{h}
\end{gathered}
$$

$\mathrm{T} \ldots$

\begin{tabular}{l}
\hline \\
$\rho$
\end{tabular}$\square \square \square \square \square \square$ $\rho \quad \square \square \square \square \square$

$\square_{s} \ldots . .$.

$\square_{\mathrm{g}} \ldots$

$\mathrm{C}_{\mathrm{ps}} \ldots .$.

$\mathrm{c}_{\mathrm{pg}} \ldots .$.

$\mathrm{C}_{\mathrm{p}}$

$\lambda_{\mathrm{s}} \ldots$

$\lambda_{\mathrm{g}} \ldots$

$\lambda \ldots$

$\mathrm{S}_{\mathrm{h}} \ldots$

$\mathrm{t}$

$\mathbf{x} \square \square \square \square \square \square \square \square$

$\mathrm{i}, \mathrm{j}$

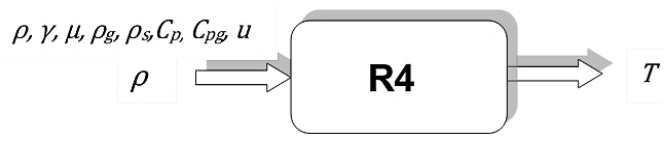

Diffusion flow equation - R5

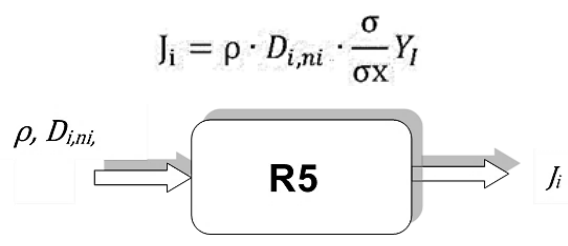

\section{STATIC RELATIONSHIP}

Weight part of component:

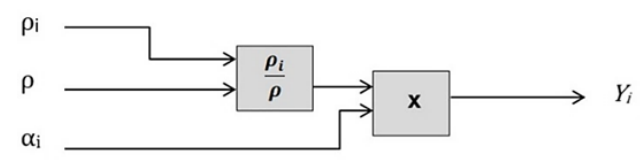

$Y_{i}=\frac{\rho_{i}}{\rho} \cdot \alpha_{i}$

Heat conductivity:

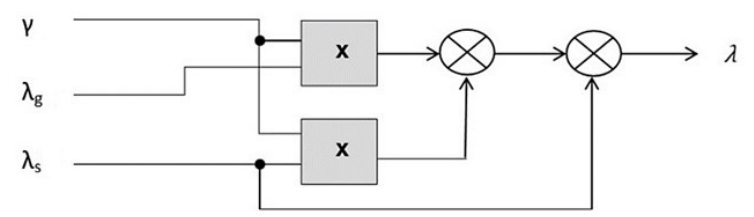

$\lambda=\gamma \cdot \lambda_{g}+(1-\gamma) \cdot \lambda_{s}$
Component origin measure:

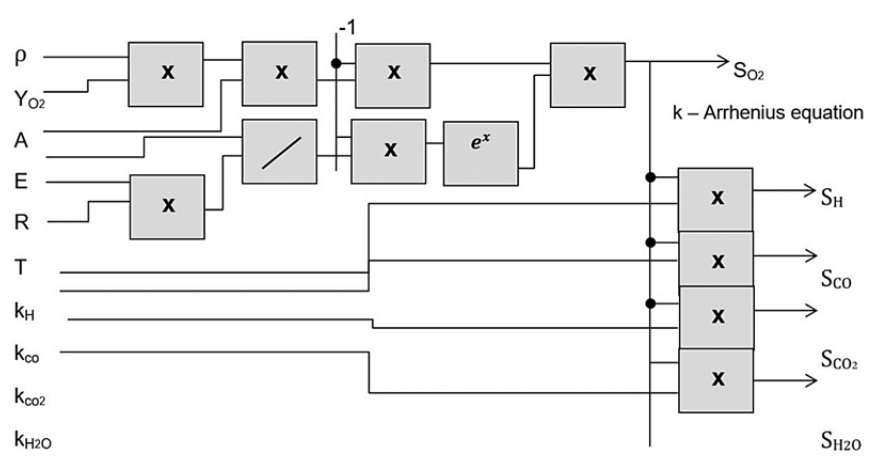

Heat conductivity:

$$
\lambda=\gamma \cdot \lambda_{g}+(1-\gamma) \cdot \lambda_{s}
$$

Source member

Oxygen $\quad S_{O_{2}}=-\rho Y_{O_{2}} A \cdot e^{\frac{-E}{R T}}$

Hydrogen $\quad S_{h}=$ const $_{h} \cdot S_{O_{2}}$

Oxide $\quad S_{\mathrm{CO}}=$ const $_{\mathrm{CO}} \cdot S_{\mathrm{O}_{2}}$

Oxide $\quad \mathrm{S}_{\mathrm{CO}_{2}}=$ const $_{\mathrm{CO}_{2}} \cdot \mathrm{S}_{\mathrm{O}_{2}}$

Water $\quad \mathrm{S}_{\mathrm{H}_{2} \mathrm{O}}=$ const $_{\mathrm{H}_{2} \mathrm{O}} \cdot \mathrm{S}_{\mathrm{O}_{2}}$

const $_{\mathrm{h}}=\mathrm{Y}_{\mathrm{h}} / \mathrm{Y}_{\mathrm{O} 2}$

const $_{\mathrm{CO}}=\mathrm{Y}_{\mathrm{CO}} / \mathrm{Y}_{\mathrm{O} 2}$

const $_{\mathrm{CO} 2}=\mathrm{Y}_{\mathrm{CO} 2} / \mathrm{Y}_{\mathrm{O} 2}$

const $_{\mathrm{H} 2 \mathrm{O}}=\mathrm{Y}_{\mathrm{H} 2 \mathrm{O}} / \mathrm{Y}_{\mathrm{O} 2}$

$\mathrm{Y}_{\mathrm{O} 2 \ldots} \quad$ weight share of oxygen

$Y_{h} \ldots \quad$ weight share of hydrogen

$\mathrm{Y}_{\mathrm{CO}} \ldots \quad$ weight share of oxygen oxide carbon monoxid

$\mathrm{Y}_{\mathrm{CO} 2 \ldots} \quad$ weight share of $\mathrm{O}_{2}$ oxide carbon dioxid

$\mathrm{Y}_{\mathrm{H} 2 \mathrm{O}} \ldots \quad$ weight share of water

\section{PREDICTION OF TIME INTERVAL TO COAL SPONTANEOUS IGNITION [4, 6, 9, 10]}

The finding of the method of timely prediction of the origin of irreversible steam situation of brown coal in coal dump bodies, coal pillars and coal products dumping grounds is the main target of this project. This target is very important for providers (mining companies) and customers (power industry). The new methodology must be areawide, quick and exact, primarily in the case of locating of irreversible steam situation possible places with the prospective of spontaneous ignition.

Predicted time interval to spontaneous ignition since last measuring:

Linear trend:

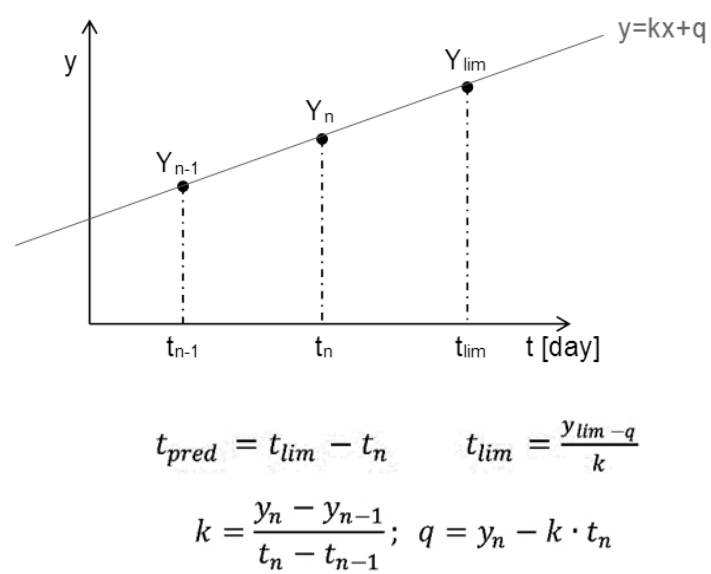


$\begin{array}{ll}\mathrm{t} \ldots & \text { time [day] } \\ \text { y } \ldots & \text { quantity } \mathrm{T}, \mathrm{CH}_{4}, \mathrm{CO}_{2}, \mathrm{CO}, \mathrm{O}_{2}\end{array}$

or with application of coefficients $\mathrm{k}$, $\mathrm{q}$ to determine by linear regression from following formula:

$$
\begin{gathered}
q=\frac{1}{n}\left[\left(y_{n-1}+y_{n}\right)-k\left(t_{n-1}+t_{n}\right)\right] ; n=2 \\
k=\frac{t_{n-1} \cdot y_{n-1}+t_{n} \cdot y_{n}}{2 \cdot\left(t_{n-1}+t_{n}\right)-\left(t_{n-1}^{2}+t_{n}^{2}\right)}
\end{gathered}
$$

Quadratic trend:

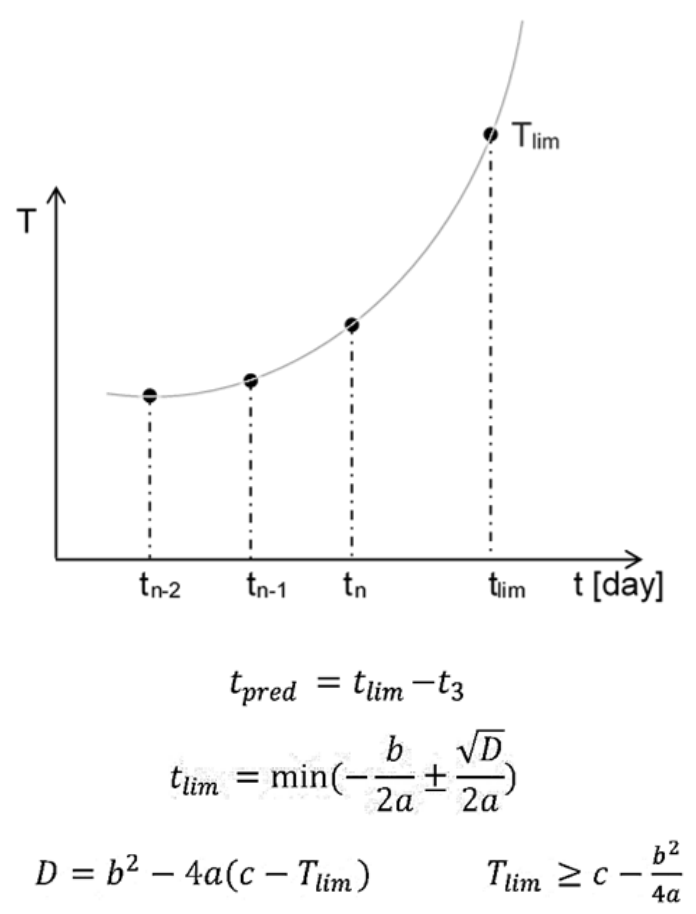

We can determine constants $a, b, c$ with application of quadratic regression for final 3 samplings, for times $t_{n-2}, t_{n-1}$, $t_{n}$ and relevant quantities, it is $\mathrm{T}, \mathrm{CO}_{2}, \mathrm{CO}, \mathrm{O}_{2}, \mathrm{CH}_{4}$. For instance temperatures $T_{n-2}, T_{n-1}, T_{n}$.

We can determine coefficients $a, b, c$ from following formulas (if this regression is not available):

$$
\begin{gathered}
a=\frac{1}{n}\left(\sum_{i=1}^{n} y_{i}-b \sum_{1}^{n} x_{i}-c \sum_{1}^{n} x_{i}^{2}\right) \\
b=\frac{z_{3}}{z_{1}}-c \cdot \frac{z_{2}}{z_{1}} \\
c=\frac{z_{1} \cdot z_{6}-z_{3} \cdot z_{4}}{z_{1} \cdot z_{5}-z_{2} \cdot z_{4}} \\
z_{1}=\sum_{1}^{n} x_{i}^{2}-\frac{1}{n}\left(\sum_{1}^{n} x_{i}\right)^{2} \\
z_{2}=\sum_{1}^{n} x_{i}^{3}-\frac{1}{n} \sum_{1}^{n} x_{i}^{2} \sum x_{i} \\
z_{3}=\sum_{1}^{n} x_{i} y_{i}-\frac{1}{n} \sum_{1}^{n} x_{i} y_{i} \\
z_{5}=\sum_{1}^{n} x_{i}^{4}-\frac{1}{n}\left(\sum_{3}^{n} x_{i}^{2}\right)^{2}
\end{gathered}
$$

For instance:

$$
\begin{aligned}
& \mathrm{X}_{1}=\mathrm{t}_{\mathrm{n}-2} \quad \mathrm{y}_{1}=\mathrm{T}_{\mathrm{n}-2} \quad \mathrm{n}=3 ; \mathrm{i}=1,2,3 \text {, } \\
& X_{2}=t_{n-1} \quad y_{2}=T_{n-1} \\
& \mathrm{X}_{3}=\mathrm{t}_{\mathrm{n}} \quad \mathrm{y}_{3}=\mathrm{T}_{\mathrm{n}} \quad \mathrm{y} \text { signified (in sequence) } \mathrm{T}, \mathrm{CO}_{2} \text {, } \\
& \mathrm{CO}, \mathrm{O}_{2}, \mathrm{CH}_{4} \text {. }
\end{aligned}
$$

\section{CONCLUSION}

This methodology of "the evaluation of the brown coal spontaneous ignition danger level in dump bodies" was realised on the grounds of numerical formulation of criterion MHU by summing of individual indicators of point load. These indicators are described in this article. The indicators of group D (additional parameters) are evaluated by "minus" points. They represent the possibility how to reduce a negative evaluation of the concrete dump. The verification of this new methodology of coal dumps evaluation was realised in this (final) year of TA01020351 programme ALFA project solving. Specialists with great experience in this field of research comment this proposition. This article introduces the final version of evaluation after the opponent comments. It is a fundamental groundwork for a creation of a certified methodology "The evaluation of risk degree for the process of a brown coal spontaneous ignition on dumps (CRITERION MHU)" and software "The application for a prediction of the coal spontaneous ignition PREDISAM".

The prediction of brown coal spontaneous ignition origin is the main result. These new knowledge allow to eliminate the danger of the mining fire in the open pit mine brown coal seam or in the coal dump bodies.

\section{ACKNOWLEDGEMENT}

This paper was prepared in the frame of the project no. TA01020351 - ALFA programme - with the financial support from the Technological agency of the Czech Republic

\section{REFERENCES}

[1] B. Taraba, V. Voráček and V. Král, “Analýza případů samovzněcování uhlí $v$ dolech OKR - část I: Nový způsob hodnocení Rizika vzniku procesu samovznícení uhlí ve stěnových porubech", Uhlí, rudy, geologický průzkum, vol. 13, no. 11, pp. 34-37, 2006.

[2] B. Taraba, Z. Pavelek, J. Janek, V. Voráček and V. Král, "Analýza prípadů samovzněcování uhlí v dolech okr část II: Hodnocení požárního ohrožení porubu z hlediska provedení adekvátních represivních zásahů", Uhli, rudy, geologický průzkum, vol. 13, no. 12, pp. 2831, 2006.

[3] B. Taraba, Nízkoteplotní oxidace a samovzněcování uhelné hmoty. Ostrava: Ostravská Univerzita, 2003.

[4] V. Moni and B. Taraba, "Laboratorní šetření významu základních parametrů ovlivňujících oxidaci hnědých uhlí", Zpravodaj HU, no. 2, pp. 17-24, 2013.

[5] X.D. Chen and J.B. Stott, "The effect of moisture content on the oxidation rate of coal during nearequilibrium drying and wetting at $50^{\circ} \mathrm{C}^{\prime \prime}$, Fuel, vol. 72, no. 6, pp. 787-792, 1993.

[6] V. Dobal, I. Sýkorová, F. Valeška and B. Hemelíková, "Metody stanovení aktivity hnědých uhlí ke kyslíku", research report, ÚGG ČSAV, Czech Republic, Prague, 1983.

[7] F. Akgun and A. Arisoy, "Effect of particle size on the spontaneous heating of a coal stockpile", Combustion and Flame, vol. 99, no. 1, pp. 137-146, 1994. 
[8] Z. Michalec, V. Michalcová and B. Taraba, "Modelování vlivu parametrů uhelné skládky na dynamiku samovzněcovacího procesu", Zpravodaj $H U$, no. 1, pp. 3-10, 2013.

[9] V. Moni, "Vyhodnocení komplexních dlouhodobých měření na hnědouhelných skládkách", Zpravodaj HU, no. 2, pp. 27-35, 2014.

Ing. Petr Klouda, Ing. Vlastimil Moni, Ph.D., RNDr. Michal Řehoř, Ph.D.

Brown Coal Research Institute j. s. C., Most

tř. Budovatelů 2830/3, 43401 Most, CZECH REPUBLIC

e-mail:moni@vuhu.cz, klouda@vuhu.cz

Ing. Jan Blata, PhD., Doc. Ing. František Helebrant, CSc

VŠB- Technical University of Ostrava

17.listopadu 15, 70833 Ostrava-Poruba, CZECH REPUBLIC

e-mail: jan.blata@vsb.cz,

frantisek.helebrant@vsb.cz
[10] B. Taraba, Z. Michalec, V. Michalcová, T. Blejchař, M. Bojko and M. Kozubková, "CFD simulations of the effect of wind on the spontaneous heating of coal stockpiles", Fuel, vol. 118, pp. 107-112, 2014.

[11] B. Taraba, R. Peter and V. Slovák, "Calorimetric investigation of chemical additives affecting oxidation of coal at low temperatures", Fuel Processing Technology, vol. 92, no. 3, pp. 712-715, 2011. 